\title{
Library Building Construction Among Colleges and Universities, I950
}

$\mathrm{Dr}$. Muller is director, University $\mathrm{Li}$ braries, Southern Illinois University, Carbondale, and chairman, A.C.R.L. Committee on College and University Library Buildings.

$\mathrm{H}$ ERE are two typical recent inquiries addressed to the A.C.R.L. Committee of College and University Library Buildings :

(Mar. 15, 1950)-I am writing-to inquire if you have a record of colleges and small universities which have recently built new buildings with modular plans. If there are any such libraries in our area, we might visit them, or at least make inquiries as to their plans and the success of them-

(Dec. I0, 1949) -What I should like to have is a list of buildings which have been completed or planned within the past year or two, with figures on total book capacity and seating capacity.

Such inquiries have come from all parts of the country as well as from overseas. To supply the requested information, a questionnaire survey of institutions listed in American Universities and Colleges (American Council on Education, 1948, 5th ed., edited by $A$. J. Brumbaugh) was conducted in the fall of 1949 . It is planned to publish the data that have been collected in several instalments, of which this article is the first one. The tabulations presented here give statistics on college and university library buildings that were under construction at the end of 1949 or for which contract drawings have been completed. Tabulations sub- sequently to be published will list ( I) library buildings completed between 1929 and 1949 and (2) institutions that expect to construct new library buildings in the near future.

It should be noted that the tabulations cover only those institutions that returned questionnaires. Information on buildings of institutions that failed to return questionnaires might be obtained from various other sources, such as back files of the Library Journal, College and Research Libraries, and the Proceedings of the (Cooperative) Committee on College and University Library Building Plans, of which Ralph Ellsworth, director of libraries, State University of Iowa, has been chairman during 1949-50.

The tabulations should prove useful to librarians, architects, and college authorities in making the budget and size estimates for library building construction and equipment. Since the size of the 24 institutions vary within a wide range, it should not be too difficult to locate an institution that resembles the one for which a new library building is to be planned. Any library building should, of course, be designed with due regard to the special conditions existing on a particular campus, such as the anticipated rate of growth in enrolment and book collections, the nature of the curriculum, degree of centralization desired, climate, prevailing architectural style, and the availability of funds.

Rank Order

In the accompanying tabulation, the insti- 
College and University Library Buildings Under Construction and Buildings for Which Contract Drawings Have Been Completed January 1950

(Arranged in the Order of Estimated Total Floor Area)

\begin{tabular}{|c|c|c|c|c|c|c|c|}
\hline (I) & (2) & (3) & (4) & (5) & (6) & (7) & (8) \\
\hline Name of Institution & $\begin{array}{l}\text { Minimum } \\
\text { No. of } \\
\text { Volumes } \\
\text { Planned } \\
\text { for }\end{array}$ & $\begin{array}{l}\text { Minimum } \\
\text { No. of } \\
\text { Seats } \\
\text { Provided }\end{array}$ & $\begin{array}{l}\text { Estimated } \\
\text { Cost in } \\
\text { dollars } \\
\text { (including } \\
\text { equipment) }\end{array}$ & $\begin{array}{l}\text { Enroll- } \\
\text { ment } \\
\text { Fall, } \\
\text { I } 94^{b}\end{array}$ & $\begin{array}{l}\text { Total No. } \\
\text { of Volumes } \\
\text { in Library } \\
\text { System }\end{array}$ & $\begin{array}{l}\text { No. of } \\
\text { Vols. in } \\
\text { Old Main } \\
\text { Bldg., } \\
\text { Dec. } 48\end{array}$ & $\begin{array}{l}\text { Notes } \\
\text { (x denotes "under construction") }\end{array}$ \\
\hline $\begin{array}{l}\text { State U. of Iowa, Iowa City, Ia. } \\
\text { Wash. State Coll., Pullman, Wash. } \\
\text { St. Louis U., St. Louis, Mo. }\end{array}$ & $\begin{array}{l}I, \infty 00, \infty 00 \\
I, 500, \infty 00 \\
I, \infty 00, \infty 00\end{array}$ & $\begin{array}{l}2,500 \\
2,200 \\
1,500\end{array}$ & $\begin{array}{l}1,580,000 \\
3,000,000 \\
1,500,000\end{array}$ & $\begin{array}{r}10,550 \\
6,530 \\
10,015\end{array}$ & $\begin{array}{l}589, I_{14} \\
610,000 \\
439,741\end{array}$ & $\begin{array}{l}150,000 \\
600,000 \\
200,000\end{array}$ & $\begin{array}{c}\text { x (modular) } \\
\text { Completed Jan. '5o (modular) }\end{array}$ \\
\hline $\begin{array}{l}\text { U. of Wisconsin, Madison, Wis. } \\
\text { U. of Mississippi, University, Miss. } \\
\text { Queens Coll., Flushing, N.Y. }\end{array}$ & $\begin{array}{r}I, 200,000 \\
450,000 \\
300,000\end{array}$ & $\begin{array}{l}2,000 \\
1,250 \\
1,333\end{array}$ & $\begin{array}{l}5,900,000 \\
1,250,000 \\
2,800,000\end{array}$ & $\begin{array}{r}22,353 \\
3,320 \\
2,915\end{array}$ & $\begin{array}{r}687,500 \\
121,782 \\
67,348\end{array}$ & $\begin{array}{l}700,000^{d} \\
\text { I } 39,041 \\
?\end{array}$ & $\begin{array}{l}\mathbf{x} \\
\mathbf{x}\end{array}$ \\
\hline $\begin{array}{l}\text { Miss. St. Coll., State Coll., Miss. } \\
\text { Woman's Coll., U. of N.C., Greensboro, N.C. } \\
\text { Mass. Inst. of Tech., Cambridge, Mass. }\end{array}$ & $\begin{array}{l}350,000 \\
300,000 \\
350,000\end{array}$ & $\begin{array}{r}850 \\
1,000 \\
500\end{array}$ & $\begin{array}{r}950,000 \\
1,150,000 \\
3,500,000\end{array}$ & $\begin{array}{l}3,571 \\
2,120 \\
5,393\end{array}$ & $\begin{array}{r}80,696 \\
123,361 \\
405,444\end{array}$ & $\begin{array}{c}? \\
130,000 \\
300,000\end{array}$ & $\begin{array}{l}\text { Completed April '50 } \\
\text { Completed Jan.'50 }\end{array}$ \\
\hline $\begin{array}{l}\text { U. of Miami, Coral Gables, Fla. } \\
\text { Eastern Ill. St. T Coll., Charleston, Ill. } \\
\text { Northern Ill. St. T Coll., DeKalb, Ill. }\end{array}$ & $\begin{array}{l}300,000 \\
175,000 \\
175,000\end{array}$ & $\begin{array}{l}700 \\
750 \\
750\end{array}$ & $\begin{array}{l}500,000^{\circ} \\
2,000,000 \\
2,100,000\end{array}$ & $\begin{array}{l}8,598 \\
1,423 \\
2,068\end{array}$ & $\begin{array}{r}114,632 \\
66,144 \\
64,925\end{array}$ & $\begin{array}{l}? \\
66,000 \\
72,000\end{array}$ & $\begin{array}{l}\text { Completed Mar.' '50 } \\
\text { Contract let in ' } 49\end{array}$ \\
\hline $\begin{array}{l}\text { Loyola U., New Orleans, La. } \\
\text { North Dakota Agric. Coll., Fargo, N.D. } \\
\text { West Virginia St. Coll., Institute, W.Va. }\end{array}$ & $\begin{array}{l}250,000 \\
200,000 \\
178,000\end{array}$ & $\begin{array}{l}515 \\
560 \\
500\end{array}$ & $\begin{array}{l}850,000 \\
500,000 \\
?\end{array}$ & $\begin{array}{l}3,099 \\
2,397 \\
1,542\end{array}$ & $\begin{array}{l}80,628 \\
60,659 \\
31,351\end{array}$ & $\begin{array}{l}80,000 \\
88,000 \\
33,242\end{array}$ & $\begin{array}{l}x \\
x\end{array}$ \\
\hline $\begin{array}{l}\text { North Carolina Coll., Durham, N.C. } \\
\text { Bradley U., Peoria, Ill. } \\
\text { Mount Union Coll., Alliance, Ohio }\end{array}$ & $\begin{array}{l}200,000 \\
\text { I } 50,000 \\
200,000\end{array}$ & $\begin{array}{l}400 \\
500 \\
338\end{array}$ & $\begin{array}{l}725,000 \\
600,000 \\
580,000\end{array}$ & $\begin{array}{r}972 \\
3,637 \\
1,002\end{array}$ & $\begin{array}{l}33,212 \\
62,872 \\
75,000\end{array}$ & $\begin{array}{l}36,461 \\
72,000\end{array}$ & Completed Summer '5o (modul.ur) \\
\hline $\begin{array}{l}\text { Rollins Coll., Winter Park, Fla. } \\
\text { Mills Coll., Oakland, Calif. } \\
\text { Ouachita Coll., Arkadelphia, Ark. }\end{array}$ & $\begin{array}{r}160,000 \\
165,000 \\
65,000\end{array}$ & $\begin{array}{l}300 \\
200^{e} \\
450\end{array}$ & $\begin{array}{l}500,000 \\
400,000 \\
125,000\end{array}$ & $\begin{array}{l}630 \\
657 \\
818\end{array}$ & $\begin{array}{r}80, \infty 00 \\
102,589 \\
23,973\end{array}$ & $\begin{array}{r}40,000 \\
108,629 \\
30,000\end{array}$ & Completed: Summer '5o \\
\hline $\begin{array}{l}\text { Converse Coll., Spartanburg, S.C. } \\
\text { Taylor U., Upland, Ind. } \\
\text { Fairmont St. Coll., Fairmont, W.Va. }\end{array}$ & $\begin{array}{l}87,000 \\
65,000 \\
64,000\end{array}$ & $\begin{array}{l}300 \\
250 \\
250\end{array}$ & $\begin{array}{l}230,000 \\
160,000 \\
400,000\end{array}$ & $\begin{array}{r}383 \\
535 \\
1,167\end{array}$ & $\begin{array}{l}36,500 \\
22,500 \\
33,300\end{array}$ & $\begin{array}{c}38,500 \\
? ? \\
33,300\end{array}$ & $\mathbf{x}$ \\
\hline
\end{tabular}

a Cost of first unit only

$\checkmark$ U. S. Office of Education, Educational Directory: Higher Education, I949-50 (Part III)

c American Library Directory, 1948 (Bowker, I948)

$d$ Excludes newspapers, pamphlets, manuscripts

- Excludes 75 carrels 
tutions are arranged in the rank order of estimated total floor area. Since data on total building size were not uniformly available for all institutions, estimates had to be made on the basis of proposed capacity for volumes plus number of seats, allowing 25 square feet per reader, I square foot per I 5 volumes, and 40 per cent of the entire building for mechanical equipment, main stairways, elevators, office space, main corridors, auditorium, and other spaces not directly used for the accommodation of books and readers. (Stack desks were considered to be part of the available floor area; no attention was paid to the cubage of the buildings.)

\section{Cost}

Column 4 reveals wide variations in cost. It is not fair to make rigid unit cost comparison until it is known what features are expected to be included in each building, such as air conditioning, an auditorium, audiovisual facilities, faculty offices, and class rooms. The manner in which the contract is let, the architectural style, and the degree of lavishness in furnishings also affect the unit cost. The cost of the building of M.I.T., which appears to be disproportionately high, may be explained by the provision of unusually ample faculty offices, conference rooms, and exhibit areas. Other buildings that are expected to be above average in cost are those of two Illinois state teachers colleges, Queens College, and the University of Wisconsin. Low-cost buildings appear to be those of the University of Iowa, St. Louis University, Ouachita College and Taylor University, unless the quotations of cost represent serious underestimates.

\section{Modular Design}

Column 8 shows that only four of the 24 buildings seem to follow modular design; and only one of them (North Dakota Agricultural College) uses hollow supporting columns as ventilation ducts, following the pioneer, Hardin-Simmons University, which completed its modular library and administration building in 1949 .

\section{Seating Capacity}

Wide variations in seating capacity as related to enrolment is revealed by comparing columns 3 and 5. Some colleges expect to provide seats for over 60 per cent or more of the total current student body (Converse College, Ouachita College, Taylor University), possibly in anticipation of future increases in enrolment. Others provide for less than 15 per cent (Bradley University, M.I.T., University of Miami, University of Wisconsin), either because enrolment is eventually expected to drop or because of the existence of many departmental libraries.

\section{Volume Capacity}

All but one of the institutions provide for a volume capacity larger than that of their present main building (if they have one). The one exception is M.I.T., where the present main building apparently houses departmental collections that will not be transferred to the new building. Some colleges provide book storage areas for over three times their present holdings (North Carolina College, West Virginia State College, Mississippi State College, Queens College, University of Mississippi), reflecting an accelerated acquisitions program or an effort to bring scattered departmental collections into a central location. Where the new building provides for less than double present total holdings, the library system is expected to continue to be departmentalized (State University of Iowa, Wisconsin) or the college sets a definite limit on the total number of volumes to be made available to its undergraduates (Mills College). Anticipation of the establishment of central storage libraries, such as the Midwest InterLibrary Center, may also have had an influence on the size of book storage facilities in library plans. 